DOI 10.15290/cnisk.2019.01.06.09

MGR KRZYSZTOF KOSSAKOWSKI

https://orcid.org/0000-0001-8569-5806

Uniwersytet w Białymstoku

\title{
Królowa Melisanda i jej siostry
}

\section{Streszczenie}

Artykuł dotyczy czterech córek króla Jerozolimy Baldwina II, stosunków między nimi oraz ich wpływu na wydarzenia w Ziemi Świętej w XII w. Spośród wszystkich czterech sióstr wpływy najstarszej z nich - Melisandy sięgały znacznie dalej niż pozostałych, zarówno w odniesieniu do polityki, jak i relacji rodzinnych. Dlatego w artykule skupiono się na niej. W pierwszej części przedstawiono tło historyczne, polityczne i rodzinne dla dziejów sióstr. W kolejnej scharakteryzowano wykorzystane źródła i ich autorów. Ostatnia dotyczy relacji Melisandy z siostrami, a także $z$ mężem i synem. Niestety przekazy źródłowe nie pozwalają na analizę stosunków panujących bezpośrednio między jej młodszym rodzeństwem.

Słowa kluczowe: wyprawy krzyżowe, Ziemia Święta, Jerozolima, władza

\section{QUEEN MELISENDE AND HER SISTERS}

\begin{abstract}
This article concerns four daughters of Baldwin II, King of Jerusalem, their relations and their impact on the events in the Holy Land in XII c. Amidst all four sisters, the impact of the oldest sister Melisende, both in politics and in the family, was much greater then of others. For this reason, the article focuses on her. In the first part, it shows the historical, political and domestic background for the history of the four sisters. In the next part,
\end{abstract}


there is a short description of the used sources. The last part concerns Melisende's relations with her sisters, husband and son. Unfortunately, due to the lack of sources, a closer analysis of the relations between other sisters was not possible.

Keywords: crusades, Holy Land, Jerusalem, authority

\section{Wstęp}

Nie ulega wątpliwości, że Baldwin II był jedna z postaci, które przyczyniły się do wzmocnienia i stabilizacji państw krzyżowych na początku XII w. Największy ich rozkwit przypada jednak na okres panowania Fulka Andegaweńskiego i jego syna Baldwina III.

Ślub Baldwina z Morfią miał miejsce zapewne około 1101 r., czyli rok po przejęciu przez niego władzy w hrabstwie Edessy. Jego małżeństwo $z$ córką namiestnika Meliteny było prawdopodobnie jednym $z$ pierwszych związków krzyżowców z miejscowymi kobietami w Ziemi Świętej, a ich najstarsza córka Melisanda była jednym $z$ pierwszych dzieci krzyżowców urodzonych na Wschodzie ${ }^{1}$. Fakt zawierania związów małżeńskich $z$ miejscowymi miał ogromne znaczenie. W ten sposób przybysze z Zachodu dawali wyraźnie do zrozumienia, że to jest ich nowy dom. Sami także wrastali w zastaną kulturę, jednocześnie wnosząc do niej wkład własny. W ten sposób córki Baldwina i Morfii miały związek jednocześnie ze Wschodem i Zachodem. Jako dzieci krzyżowca i armeńskiej księżniczki wychowywały się w specyficznych warunkach i na pewno lepiej rozumiały realia panujace na Bliskim Wschodzie niż przybysze z Zachodu.

Melisanda urodziła się zapewne około 1105 r., Alicja w 1108 r., Hodierna w 1110 r., a najmłodsza Jowita w 1120 r. Trzy starsze siostry urodziły się, gdy ich ojciec był jeszcze hrabia Edessy, ale najmłodsza pojawiła się już po jego koronacji. Trzy $z$ nich zostały $z$ czasem władczyniami $^{2}$ państw krzyżowych, a ostatnia była opatka dużego i znaczącego

\footnotetext{
1 Steven Runciman, Dzieje wypraw krzyżowych, przeł. Jerzy Schwakopf, (Warszawa : Państwowy Instytut Wydawniczy, 1987), t. 2, 168-169.

2 Pojęcie „władczyni” jest w tym artykule raczej skrótem myślowym niż odniesieniem do kwestii formalno-prawnych, ponieważ $z$ formalnego punktu widzenia żadna $z$ sióstr nie władała samodzielnie - zawsze razem $z$ mężem, w jego imieniu, jeśli trafił do niewoli, lub $\mathrm{w}$ imieniu nieletniego syna.
} 
klasztoru żeńskiego w Betanii ${ }^{3}$. Jako pierwsza za mą̇ wyszła druga $z$ sióstr, czyli Alicja. Ślub z Boemundem II zapewnił jej tron Antiochii. Warto też zauważyć, że jej mąż, mimo że był synem krzyżowca, nie wychował się w Outremer, tylko na Zachodzie ${ }^{4}$. Od kiedy zdał sobie sprawę, że nie będzie miał syna, Baldwin II planował osadzenie Melisandy na tronie. $\mathrm{W}$ tym celu zaaranżował jej małżeństwo $z$ Fulkiem $\mathrm{V}$ - hrabią Andegawenii i Maine. Odwiedził on Ziemię Świętą po raz pierwszy w 1120 r. i wówczas nawiązał kontakty z Baldwinem. W 1128 r. król Jerozolimy wysłał posłów, aby zaproponować mu rękę Melisandy i tron ${ }^{5}$. Ślub Hodierny miał miejsce aż dziewięć lat później. W 1137 r. wyszła za mąz za Rajmunda II - syna Ponsa $z$ Trypolisu. W tym samym roku Pons zginał jednak w bitwie i jego syn przejał po nim schedę ${ }^{6}$. Najmłodsza z sióstr nie wstapiła w związek małżeński. Została zakonnicą w klasztorze w Betanii, a po 1144 r. objęła stanowisko opatki po śmierci swojej poprzedniczki ${ }^{7}$. Wszystkie cztery siostry były w mniejszym lub większym stopniu zaangażowane w politykę, więc można się spodziewać, że ich interesy nie zawsze były zbieżne. Ponadto musiały także brać pod uwagę zdanie ojca, a następnie swoich mężów, którzy również mieli ambicje dotyczące władzy. Mimo to po lekturze źródeł można odnieść wrażenie, że siostry wspierały się wzajemnie w takim stopniu, w jakim to było możliwe. Postacie ich ojca, mężów i synów są dużo bardziej znane i znacznie częściej pojawiaja się w źródłach, ale przy uważnej analizie można dostrzec znaczące wpływy czterech sióstr. Dlatego warto sprawdzić, jakie stosunki panowały między nimi. Pozwoli to dokładniej określić ich wpływ na państwa krzyżowe.

\footnotetext{
3 Steven Runciman, Dzieje wypraw krzyżowych, t. 2, 206-207; Natasha Hodgson, Women, crusading and holy land in the historical narrative, (Woodbridge : Boydell Press, 2003), 65.

4 Regine Pernoud, Kobieta w czasach wypraw krzyżowych, przeł. Iwona Badowska, (Gdańsk: Marabut, 2002), 51; Malcolm Barber, The crusader states, (New Haven : Yale University Press, 2012), 145.

5 Joshua Prawer, Królestwo jerozolimskie. Europejski kolonializm w średniowieczu, przeł. Grzegorz Smółka, (Oświęcim : Napoleon V, 2017), 88-89; Steven Runciman, Dzieje wypraw krzyżowych, t. 2, 168-169; Malcolm Barber, The crusader states, 150.

6 John La Monte, Monarchia feudalna $w$ tacińskim królestwie jerozolimskim $w$ latach 1100-1291, przeł. Konrad Ziółkowski, (Oświęcim : Napoleon V, 2015), 178-179; Thomas Asbridge, Krucjaty. Wojna o Ziemię Święta, przeł. Natalia Rataj, Mateusz Józefowicz, (Kraków : Astra, 2015), 147; Andrew Jotischky, Crusading and the Crusader states, (New York : Taylor\&Francis Ltd, 2013), 104.

7 Regine Pernoud, Kobieta w czasach wypraw krzyżowych, 60-62.
} 


\section{Źródła}

Dla czasów Melisandy i jej sióstr nie zachowało się zbyt wiele źródeł. Najlepszym źródłem narracyjnym do tego tematu jest kronika Wilhelma $z$ Tyru. Nie ma innej kroniki pochodzacej z państw łacińskich $z$ tego okresu. Wcześniejsza kronika Fulchera $z$ Chartres (Historia Hierosolymitana ${ }^{8}$ ) urywa się na $1127 \mathrm{r}$., więc może być świadectwem tylko niewielkiej części działań córek Baldwina II. Jej autor trafił do Ziemi Świętej wraz z pierwszą krucjata, prawdopodobnie jako duchowny w armii Roberta $z$ Normandii. Podczas wyprawy został jednak kapelanem Baldwina $z$ Bouillon. Towarzyszył mu później w Edessie i zapewne również w Jerozolimie, gdzie kontynuował swoje dzieło. W 1127 r. zmarł z powodu panującej w mieście zarazy ${ }^{9}$. Skupiał się głównie na wyprawach zbrojnych i dyplomacji.

Podobne zainteresowania miał także piszący później od niego Wilhelm $z$ Tyru, choć równie wiele miejsca poświęcał sprawom wewnętrznym państw krzyżowych. Być może wynikało to $z$ faktu, że urodził się już w Ziemi Świętej, zapewne około 1130 r. Nie wiadomo, kim byli jego rodzice, ale można podejrzewać, że pochodzili z Zachodu i przybyli do Outremer $z$ pielgrzymką lub którąś $z$ wypraw zbrojnych. Na pewno jednak pochodzili ze stanu rycerskiego. $Z$ rodziny Wilhelma znany jest jeszcze tylko jego brat - Ralf, którego podpis pojawia się na pewnym dokumencie z $1175 \mathrm{r} .{ }^{10} \mathrm{O}$ Wilhelmie wiadomo też, że pobierał nauki razem z Amalrykiem - młodszym synem Melisandy i Fulka. Poza tym podróżował na Zachód i do Konstantynopola. Na pewno był także wychowawcą małoletniego Baldwina IV, syna Amalryka, od 1174 r. pełnił funkcję kanclerza królestwa Jerozolimy, a od 1175 do 1184 r. był arcybiskupem Tyru. W 1184 r. został wygnany i udał się do Rzymu, gdzie zmarł kilka lat później ${ }^{11}$. Jego wygnanie było zapewne spowodowane przynależnością

\footnotetext{
8 Steven Runciman, Dzieje wypraw krzyżowych, t. 1, 316-317.

9 Jonathan Phillips, The crusades 1095-1197, (London : Longman Pearson), 2002, 6-7.

10 William of Tyre, History of Deeds done beyond the seas, (ed.) Emily Babcock, August Krey, (New York : Columbia University Press, 1943), vol. 1, 8. Najnowsze wydanie: Robert Huygens (ed.), Willemi Tyrensis Archiepiscopi Chronicon. Corpus Christianorum Continuatio Medievalis, (Turnholt : Brepols, 1986), vol. 38, 38a. Niestety ze względu na fakt, że wydanie to jest obecnie trudno dostępne, jestem zmuszony korzystać $z$ wydań starszych. O samym Wilhelmie zob. Peter Edbury, John Rowe, William of Tyre. Historian of the Latin East, (New York : Cambridge University Press, 1990), o jego dziele: Phillip Handyside, The Old French William of Tyre, (Leiden-Boston : Brill, 2015).

11 Peter Edbury, John Rowe, William of Tyre, 167.
} 
do frakcji Rajmunda III $z$ Trypolisu i konfliktem $z$ królową Sybilla jerozolimską i jej mężem Gwidonem z Lusignan. Dzieło Wilhelma - Historia Rerum in Partibus Transmarinis Gestarum ${ }^{12}$ - prawdopodobnie powstawało jeszcze przed wygnaniem, ale autor kończył je już w Rzymie.

Uzupełnienie moga stanowić dokumenty zebrane w kilku wydawnictwach, takich jak Cartulaire general de l'Ordre du Temple, Cartulaire general de l'Ordre des Hospitalliers, Regesta Regni Hiersolymitani, Cartulaire de l'Eglise du Saint Sepulchre, Chartes de Terre Sainte i Codice diplomatico del Sacro Militare Ordine Gerosolimitano oggi di Malta ${ }^{13}$. $\mathrm{W}$ większości sa to nadania ziemskie lub pieniężne dla kościołów albo klasztorów wydawane wspólnie przez Alicję, Melisandę i Fulka, Melisandę i Baldwina III, Hodiernę i Rajmunda II bądź dokumenty sygnowane przez kogoś innego zawierające informację o zgodzie Melisandy, Alicji lub Hodierny na konkretne nadanie. Ponadto dysponujemy listami Bernarda z Clairvaux ${ }^{14}$ do Melisandy oraz kilkoma dokumentami Jowity zwiąanymi ze sprawami gospodarczymi klasztoru.

O tych czasach pisali też autorzy spoza państw krzyżowych. Z Bizancjum byli to Jan Kinnamos i Niketas Choniates, a $z$ państw tureckich ibn-al-Athir i Kamal-ad-Din. Ponadto kronikarz związany z Ludwikiem VII - Odo z Deuil pisał o przebiegu drugiej wyprawy krzyżowej, ale jego praca kończy się na przybyciu Ludwika do Antiochii ${ }^{15}$. Niestety żadne $z$ tych dzieł nie wspomina o którejkolwiek $z$ sióstr mimo opisywania wydarzeń, w których uczestniczyły lub które spowodowały.

\footnotetext{
12 Ibidem, 44-60.

${ }^{13}$ Margquis d'Albon (ed.), Cartulaire general de l'Ordre du Temple, (Paris : Honore Champion, 1913); Jean Delaville Le Roulx (ed.), Cartulaire general de l'Odre des Hospitalliers de Saint Jean de Jerusalem, (Paris : Ernest Leroux, 1844), vol. 1; Reinhold Röhricht (ed.), Regesta Regni Hierosolymitani, (Innsbruck : Academica Wagneriana, 1893); Eugene De Roziere (ed.), Cartulaire de l'Eglise du Saint Sepulcre de Jerusalem, (Paris : Imprimerie National, 1849); Francois Delaborde (ed.), Chartes de Terre Sainte, (Paris : Albert Fontemoing, 1880); Salvatore Marescandoli (ed.), Codice diplomatico del Sacro Militare Ordine Gerosolimitano oggi di Malta, (Lucca, 1733).

14 Jean-Paul Migne (ed.), Patrologiae Cursus Completus, Patrologia Latina, (Paris, 1859), vol. 182, col. 373, 494-496, 556-558; Jean LeClercq, Henri Rochais (ed.), Sancti Bernardi Opera, (Turnholt : Brepols, 1979), listy nr 206, 289, 354, 355.

15 Steven Runciman, Dzieje wypraw krzyżowych, t. 2, 436-439.
} 


\section{Przekazy źródłowe}

Paradoksalnie w źródłach najwcześniej pojawia się najmłodsza $z$ sióstr. Fulcher $z$ Chartres wspomina, że w 1125 r. Baldwin II, aby wydostać się $z$ niewoli tureckiej, musiał przekazać w zastaw swoja pięcioletnią córkę $^{16}$. Nie podaje nawet jej imienia, ale tylko Jowita miała wówczas około pięciu lat. Pozostałe siostry były już znacznie starsze. Fulcher dodał również, że dziewczynkę udało się bez problemu wykupić. Drugą i ostatnia informacja o siostrach w kronice tego autora jest wzmianka o przybyciu w 1126 r. do Ziemi Świętej Boemunda II - syna Boemunda $z$ Tarentu ${ }^{17}$. Przybył on, aby zasiasść na tronie w Antiochii i poślubić Alicję, drugą córkę Baldwina II, dzięki czemu została księżną antiocheńską. Warto zwrócić uwage na fakt, że Alicja wyszła za mąż wcześniej niż jej starsza siostra. Być może było to spowodowane tym, że Baldwin II planował osadzić ją na tronie jerozolimskim, a baronowie niechętnie widzieliby połączenie dwóch najpotężniejszych państw krzyżowych.

Ślub Melisandy miał miejsce dwa lata później - w 1128 r., o czym poinformował już Wilhelm z Tyru. Wyszła za mą̇̇ za Fulka hrabiego Andegawenii i Maine. Według kronikarza był on już wcześniej z pielgrzymka z Ziemi Świętej (około 1120 r.), a po śmierci jego pierwszej żony Baldwin wysłał do niego posłów $z$ propozycją nowego związku. Zaraz po ślubie Fulko został mianowany następcą tronu jerozolimskiego, nie ograniczyło to jednak praw Melisandy do tronu ${ }^{18}$. Wydaje się, że póki żył Baldwin, ich udział w rządach był bardzo ograniczony. Pierwszy zachowany dokument wydany przez Fulka pochodzi już $z$ okresu jego panowania ${ }^{19}$. Podobnie jest w przypadku Melisandy, $z$ wyjątkiem jej podpisów na dwóch dokumentach wydanych przez ojca w 1128 i 1130 r. $^{20}$

16 Heinrich Hagenmayer (ed.), Fulcheri Carnotensis Historia Hierosolymitana, (Heidelberg : Academica Wagneriana, 1913), 769-770; Guillaume de Tyre, Historia Rerum in partibus transmarinis gestarum. Recueil des Historiens des Croisades. Historiens Occidentaux, vol. 1, (Paris : Imprimerie Royale, 1844), 57-58; William of Tyre, History of Deeds done beyond the seas, vol. 2, 21; Yvonne Friedman, Encounter between enemies. Captivity and ransom, (Leiden : Brill, 2002), 16-17.

17 Fulcheri Carnotensis Historia Hierosolymitana, 805-807, 815-818; Guillaume de Tyre, Historia Rerum, 588-589; William of Tyre, History of Deeds done beyond the seas, vol. 2, 32-34.

18 Guillaume de Tyre, Historia Rerum, 593-594; William of Tyre, History of Deeds done beyond the seas, vol. 2, 38 .

19 Cartulaire general de l'Odre des Hospitalliers, 97-98 (nr 116).

20 Regesta Regni Hierosolymitani, 30, 34. 


\section{Melisanda i Alicja}

Trudno stwierdzić, jaką rolę odegrała Melisanda w konflikcie Alicji $z$ ich ojcem. W 1130 r. Boemund II zginał w bitwie $z$ Imadem ad-Din-Zenghim. Baldwin II udał się $z$ wojskiem do Antiochii w celu przejęcia regencji w imieniu Konstancji - nieletniej córki Alicji. Kilku mieszkańców otworzyło mu bramy, choć Alicja postanowiła nie wpuścić go do miasta. Według Wilhelma $z$ Tyru starała się nawet zawiąać sojusz z Zenghim, co jej się nie udało. Ustalono, że tron antiocheński poczeka na Konstancję, a jej matce przypadły tereny $z$ miastami Laodycea i Giblet ${ }^{21}$. Być może w negocjacjach brała udział Melisanda, która zadbała o odpowiednie uposażenie siostry, chociaż brak na to jakichkolwiek dowodów. Możliwe jest, że w przeciwnym wypadku Alicja zostałaby przywieziona przez ojca do Jerozolimy. Zwłaszcza że formalnie nie miała żadnych praw do księstwa Antiochii ani żadnej jego części. Mimo to w następnym roku, po śmierci ojca, podjęła kolejna próbę zajęcia tronu. Wilhelm $z$ Tyru stwierdził nawet, że udało jej się przekonać Ponsa $z$ Trypolisu i Joscelina $z$ Edessy do nieposłuszeństwa nowemu królowi Jerozolimy. Jej wysiłki ponownie jednak poszły na marne, ponieważ wyprawa Fulka przeciw niej okazała się skuteczna. Pons i Joscelin podporządkowali się królowi, a Alicja znowu znalazła się w Laodycei ${ }^{22}$. Podobnie jak w wydarzeniach sprzed roku, nie ma tu żadnych informacji o udziale Melisandy. Być może sam Fulko ograniczyłby jej stan posiadania, ale fakt pozostawienia Alicji wszystkich jej dotychczasowych ziem może sugerować udział jej starszej siostry. Na pewno Alicja została wykluczona $z$ negocjacji w sprawie małżeństwa jej córki Konstancji z Rajmundem z Poitiers, rozpoczętych niedługo po $1131 \mathrm{r}$.

Przed aranżacją ślubu siostrzenicy Melisanda i Fulko musieli sobie jednak poradzić $z$ kryzysem we własnym małżeństwie. Wilhelm $z$ Tyru informuje o plotkach rozchodzacych się w Jerozolimie na temat romansu królowej $z$ hrabia Jaffy Hugonem de Puiset. Sam Hugo miał się nawet pojedynkować $z$ tego powodu $z$ rycerzem króla, ale nie stawił się w szrankach. Apogeum konfliktu nastapiło, gdy Hugon został ranny w karczmie. Ludność uznała wówczas, że doszło do tego z poduszczenia króla, i wszczęła zamieszki. Fulko, aby oczyścić się z podejrzeń, zezwolił

${ }^{21}$ Guillaume de Tyre, Historia Rerum, 598-601; William of Tyre, History of Deeds done beyond the seas, vol. 2, 43-45.

22 Guillaume de Tyre, Historia Rerum, 611-616; William of Tyre, History of Deeds done beyond the seas, vol. 2, 53-58. 
na zgłaszanie skarg na siebie w sądzie. Według Wilhelma nikt się nie zgłosił, co świadczyło o niewinności króla. Za to Hugon po wyzdrowieniu musiał opuścić Outremer. Udał się na Sycylię, gdzie zmarł po kilku latach. Trudno powiedzieć, czy w plotkach było choćby ziarno prawdy, ale Wilhelm twierdził, że wszyscy przeciwnicy hrabiego Jaffy byli surowo ścigani przez Melisandę. Sprawę zakończyła dopiero ugoda zapośredniczona przez Fulka ${ }^{23}$. Może to świadczyć, że w tym wypadku plotki przynajmniej częściowo pokrywały się $z$ faktami. Nie ma jednak informacji o następstwach tej sprawy dla Melisandy. Być może wynikało to ze znacznego wpływu, jaki miała na męża, o czym pisał także Wilhelm z Tyru:

Od tamtego czasu [sprawy Hugona de Puiset] król stał się tak zależny od swojej żony, że jak wcześniej wzbudzał jej gniew, teraz starał się go łagodzić i nawet w mniej istotnych sprawach nie podejmował żadnych działań bez jej rady ${ }^{24}$.

Znajduje to też potwierdzenie w dokumentach. Wśród zachowanych pism $z$ okresu ich wspólnego panowania tylko nieliczne odnosza się do samego Fulka. Większość wprawdzie wymienia go na pierwszym miejscu, ale stosuje formułe „w porozumieniu z królowa Melisanda” (in consensu reginae Milisendis) lub podobne ${ }^{25}$. Jeszcze $z$ okresu panowania Baldwina II nie mamy zbyt wielu takich dokumentów, ale od Melisandy i Fulka norma stało się przywoływanie żony w nadaniach czynionych przez męża. Trzeba jednak dodać, że bywało tak najczęściej w wypadku (w Outremer wcale nierzadkim), gdy to kobieta dysponowała prawami do tronu, a maż zasiadał na nim tylko iure uxoris.

Po uporaniu się z własnymi problemami Melisanda ponownie mogła zająć się księstwem Antiochii. W 1135 r. do Ziemi Świętej przybył Rajmund z Poitiers, aby poślubić córkę Alicji Konstancję. Jej matka wciaż jednak snuła plany powrotu na tron. Przed przyjazdem Rajmunda zjawiła się w Antiochii, mając nadzieję, że to ja wybierze hrabia Poitiers.

\footnotetext{
${ }^{23}$ Guillaume de Tyre, Historia Rerum, 627-632; William of Tyre, History of Deeds done beyond the seas, vol. 2, 70-75.

24 Rex autem ab ea die ita factus est uxorious, ut ejus quam prius exacerbaverat, mitigaret indignationem, quod nec in causis levibusabsque ejus conscentia attentaret aliquatenus prosedere (Guillaume de Tyre, Historia Rerum, 633; William of Tyre, History of Deeds done beyond the seas, vol. 2, 76).

25 Cartulaire general de l'Ordre des Hospitalliers, vol. 1, 113-114 ( $\mathrm{nr} 139), 130$ (nr 160), 135-136 (nr 173); Cartulaire de l'Eglise du Saint Sepulcre, 58-59 ( $\mathrm{nr} 23), 65-68$ ( $\mathrm{nr} 34)$; Chartes de Terre Sainte, 80-82 (nr 33, 34) i wiele innych.
} 
Fulko tym razem nie interweniował, według Wilhelma $z$ Tyru dzięki wpływom Melisandy. Okazało się, że jej ocena sytuacji była wyjątkowo trafna, ponieważ Rajmund zgodnie $z$ planem poślubił Konstancję, a zniechęcona Alicja wróciła do Laodycei ${ }^{26}$. Trudno obecnie stwierdzić, na ile było to wynikiem zakulisowych działań królowej, a na ile samodzielnych decyzji poszczególnych bohaterów dramatu. Zdaniem Wilhelma $z$ Tyru jeszcze dwa-trzy lata później Alicja doprowadziła do wyprawy cesarza Jana Komnena na Antiochię ${ }^{27}$. Nie potwierdzaja tego jednak źródła bizantyńskie (Jan Kinnamos i Niketas Choniates). Tak czy inaczej wydaje się, że była to jej ostatnia aktywność na scenie politycznej, choć z zachowanych dokumentów wynika, że żyła w Laodycei jeszcze co najmniej do 1145 r. $\mathrm{Na}$ ten rok datowany jest ostatni dokument wydany przez nia sama ${ }^{28}$. W 1151 r. jej córka Konstancja wystawiła dokument wycofujący pewne decyzje matki, co może świadczyć, że Alicja już wówczas nie żyła ${ }^{29}$. Niestety ze względu na odcięcie Alicji, dobrowolne lub nie, od spraw politycznych nie da się bardziej zawęzić tych ram.

\section{Melisanda i Hodierna}

Trzecia $z$ sióstr pojawia się w źródłach znacznie rzadziej niż dwie starsze. W 1137 r. wyszła za mąż za Rajmunda II - syna Ponsa z Trypolisu. W tym samym roku została też hrabina, ponieważ stary hrabia zginą w bitwie. Jej związek trudno jednak uznać za szczęśliwy. Regine Pernoud w swojej ksiażce Kobieta $w$ czasach wypraw krzyżowych stwierdziła, że mąż był o nią chorobliwie zazdrosny i starał się ograniczać jej wolnośćc ${ }^{30}$. Trudno powiedzieć, na ile jest to zgodne $z$ prawdą, ponieważ nie mamy żadnych informacji o prywatnych stosunkach Hodierny i Rajmunda aż do 1152 r. Wiadomo, że wcześniej często występowała razem z mężem

\footnotetext{
${ }^{26}$ Guillaume de Tyre, Historia Rerum, 635-636; William of Tyre, History of Deeds done beyond the seas, vol. 2, 77-79.

27 Guillaume de Tyre, Historia Rerum, 641-642; William of Tyre, History of Deeds done beyond the seas, vol. 2, 83. Zarówno Kinnamos, jak i Choniates nie słyszeli o doprowadzeniu do wyprawy Jana Komnena na Antiochię przez Alicję - według nich Jan zamierzał przyłączyć Antiochię do Bizancjum, a nie oddawać ją komuś innemu (John Kinnamos, The Deeds of John and Manuel Comnenus, transl. Charles Brand, (New York : Columbia University Press, 1976), 23; O City of Byzantium. Annals of Nicetas Choniates, transl. Harry Magoulias, (Detroit : Wayne State University Press, 1984), 15-16.

28 Cartulaire general de l'Ordre des Hospitalliers, vol. 1, 131 (nr 163).

29 Ibidem, 153-154 (nr 198); Regesta Regni Hierosolymitani, 67.

30 Regine Pernoud, Kobieta w czasach wypraw krzyżowych, 88-90.
} 
jako wystawca dokumentów lub na listach świadków pism wydanych przez jego kancelarię, czasem razem $z$ matką Rajmunda Cecylia, królową Melisanda, a także razem $z$ para ksiązęca $z$ Antiochiii ${ }^{31}$. Warto też zauważyć, że w 1148 r. Rajmund został bohaterem skandalu związanego ze śmiercią hrabiego Tuluzy Alfonsa Jordana. Zmarł on niedługo po przybyciu do Ziemi Świętej, a po klęsce wyprawy rozeszły się plotki o jego otruciu właśnie przez Rajmunda, który obawiał się pretensji Alfonsa do swojego hrabstwa ${ }^{32}$. Nie wiadomo, czy było w nich choćby ziarno prawdy, czy stanowiły część wzajemnych oskarżeń między Wschodem a Zachodem po nieudanej krucjacie.

Trudno $z$ pewnością stwierdzić, jakie stosunki panowały między Hodierna a jej mężem, ale wydaje się, że albo do 1152 r. nie były zupełnie złe, albo Melisanda starała się wcześniej do nich nie mieszać. Regine Pernoud ostrożnie daje pod rozwagę, że spory małżeńskie Hodierny, podobnie jak kiepska reputacja jej męża, mogły mieć korzenie w drugiej krucjacie i historii pewnego trubadura, Joffre’a Rudela. Według pieśni miał on zakochać się w hrabinie (ani razu jej nie widzac) i przybył do Outremer, aby ja poznać. Zachorował jednak po drodze i bliski śmierci wylądował w Trypolisie, gdzie zmarł w jej ramionach. Mimo zgonu adoratora Rajmund miał być bardzo zazdrosny ${ }^{33}$. Wydaje się, że jest to raczej kwestia modnej wówczas miłości dworskiej przekazana w formie popularnych pieśni. W każdym razie Melisanda dopiero we wspomnianym $1152 \mathrm{r}$. zdecydowała się odwiedzić Trypolis i starała się pogodzić Hodiernę z Rajmundem. Niestety Wilhelm $z$ Tyru najpewniej sam nie wiedział, czego dokładnie ten konflikt dotyczył (nie wspomina o Joffre’em). Według niego nie udało jej się doprowadzić do zgody, ale postanowiła zabrać siostrę ze soba do Jerozolimy. Mogłoby to oznaczać, że sprawa była poważna, a sam fakt, że postawiła na swoim w sporze $z$ jednym $z$ najpotężniejszych wasali, świadczy też o jej sile i zdecydowaniu. Rajmund towarzyszył im w części drogi do stolicy, po czym zawrócił do Trypolisu, gdzie został zamordowany na ulicy przez asasynów. Na wieść o tym doszło w mieście

31 Cartulaire general de l'Ordre des Hospitalliers, vol. 1, 116-118 (nr 144), 154 (nr 199); Regesta Regni Hierosolymitani, 47, 49, 53, 55, 58, 68; Codice diplomatico, 19 (nr 18), 23 (nr 23).

32 Regine Pernoud, Kobieta w czasach wypraw krzyżowych, 89; Jonathan Phillips, Druga krucjata. Rozszerzanie granic chrześcijaństwa, przeł. Norbert Radomski, (Poznań : Rebis, 2013), 306-307.

33 Regine Pernoud, Kobieta w czasach wypraw krzyżowych, 89. 
do pogromu muzułmanów, a Baldwin III, który również tam przebywał, wezwał Melisandę i Hodiernę $z$ powrotem. Nakazał też złożenie hołdu Hodiernie i jej dzieciom - dwunastoletniemu wówczas Rajmundowi (III) i jego młodszej siostrze Melisandzie ${ }^{34}$. Automatycznie ich matka została regentką na czas niepełnoletności syna, a konieczność wyjazdu zniknęła wraz $z$ nielubianym mężem. Nikt jednak nie podejrzewał królowej i jej siostry o zaaranżowanie zamachu na hrabiego Trypolisu i to mimo faktu, że zabójstwo zdarzyło się w wyjątkowo sprzyjającym im czasie i okolicznościach.

Nie mamy już żadnych precyzyjnych informacji o Hodiernie po 1152 r. Wiadomo, że pełniła funkcję regentki co najmniej do 1155 r. $\mathrm{w}$ imieniu Rajmunda III. Wilhelm z Tyru podaje jeszcze, że wraz z Jowita była obecna w 1161 r. przy umierającej Melisandzie ${ }^{35}$. Sama Hodierna zmarła zapewne przed 1164 r., ponieważ wówczas, kiedy Rajmund III trafił do niewoli, to król Jerozolimy pełnił funkcję regenta w hrabstwie.

\section{Melisanda i Jowita}

W latach 40. XII w. także najmłodsza $z$ sióstr pojawiła się wreszcie w kronice Wilhelma $z$ Tyru. Według niego Jowita (lub Iveta) już wcześniej wstapiła do klasztoru św. Anny w Jerozolimie, ale Melisanda uznała, że córka króla nie powinna być podporządkowana matce przełożonej jak każda inna mniszka, i dlatego ufundowała klasztor św. Łazarza w Betanii. Decyzję musiała podjąć już znacznie wcześniej, ponieważ zdaniem kronikarza nakazała budowę ufortyfikowanej wieży i kościoła oraz nadała klasztorowi znaczne posiadłości, w tym Jerycho $z$ okolicznymi wsiami. Celowo też pierwszą opatka została wiekowa zakonnica, tak aby w odpowiednim momencie zwolniła miejsce najmłodszej siostrze królowej. Wilhelm umieszcza to wydarzenie jeszcze przed śmiercią króla, czyli przed 1143 r. W rzeczywistości jednak miało ono miejsce już po 1144 r. Na ten rok datowany jest dokument Baldwina III wymieniający w formule datum per manus Matyldę - opatkę klasztoru św. Łazarza w Betanii ${ }^{36}$. Nawet biorac pod uwagę błędy chronologiczne autora, można założyć,

\footnotetext{
${ }^{34}$ Guillaume de Tyre, Historia Rerum, 791-792; William of Tyre, History of Deeds done beyond the seas, vol. 2, 214-215.

35 Guillaume de Tyre, Historia Rerum, 795, 812-813; William of Tyre, History of Deeds done beyond the seas, vol. 2, 283, 291.

${ }_{36}$ Regesta Regni Hierosolymitani, 57.
} 
że Jowita została matka przełożoną dużego klasztoru żeńskiego w wieku dwudziestu kilku, najwyżej trzydziestu lat. Wszystko odbyło się za zgodą patriarchy i mieszkajacych tam zakonnic.

Niestety Jowita pojawia się w źródłach jeszcze rzadziej niż Hodierna. Pozostał po niej tylko jeden dokument, z 1157 r., dotyczacy wymiany dóbr $z$ joannitami. Jest on interesujący przede wszystkim ze względu na listę świadków, na której poza Melisandą znajdują się matki przełożone wielu klasztorów żeńskich w królestwie Jerozolimy. Można odnieść wrażenie, że pismo powstało podczas jakiegoś spotkania, które byłoby doskonałym sposobem na rozszerzanie zakulisowych wpływów Melisandy i Jowity. Dowodem na takie wpływy mogłaby być relacja Wilhelma z Tyru dotyczaca wyboru patriarchy w 1157 r.:

Prałaci Kościoła zebrali się w Jerozolimie, aby tam, zgodnie $z$ prawem kanonicznym, debatować nad wyborem następcy, który wstapiłby na tak ważny tron. Mówi się, że przez interwencję siostry królowej Melisandy i hrabiny Sybilli z Flandrii - siostry króla, wybór został dokonany niekanonicznie i wybrany został Amalryk - opat kościoła Grobu Świętego. ... Jego elekcji sprzeciwili się Hernezjusz - biskup Cezarei i Ralph - biskup Betlejem. Po objęciu tronu Amalryk zostawił sprawy w rękach Fryderyka - biskupa Akki ... Mówi się, że dzięki darom Fryderyk zapewnił życzliwość biskupa Rzymu dla sprawy Amalryka ${ }^{37}$.

Wygląda na to, że współpraca Melisandy i Jowity z Sybillą z Flandrii układała się bardzo pomyślnie, skoro były w stanie wpłynąć na wybór, który zazwyczaj pozostawał w gestii biskupów królestwa. Niewykluczone też, że siostry w podobny sposób wpływały na elekcję poprzedniego patriarchy Fulka w 1146 r., ale w tym wypadku brakuje na to jakichkolwiek dowodów

\footnotetext{
37 Ecclesiarum praelatos Hierosolymam convenire, ut de substituendo tantae sedi antistitie, secundam statua canonorum, tractaretur. Factum est autem, ut dicitur, quod contra juris regulas, tam, per interventum, dminae Milissendis sorore, quam domina Flandrensium comitissa Sibylla, domini regis itidim sorore, electus est dominus Amalricus, ecclesiae Dominici sepulchri prior ... contradicentibus domino Hernesio Caesariensi archiepiscopo et domino Radulpho Betlheemita episcopo, et appellationum voces exhibentibus. Tandem ille sede potitus, domino Frederico Acconensi episcopo negotium commitit, qui ad romanam eccedens ecclesiam, apud dominum Hadrianum, qui tunc praerat, absentibus adversariis, multa, ut dicitur, interveniente munificentia, eidem gratiam romanae sediis obtinuit, et pallium, plentitudinem videlicet pontificalis officii, secum detulit rediens (Guillaume de Tyre, Historia Rerum, 854; William of Tyre, History of Deeds done beyond the seas, vol. 2, 271-272).
} 
Niestety o Jowicie w późniejszym okresie nie wiemy już niemal nic. Zachował się dokument Baldwina IV z 1175 r., który wymienia opatkę klasztoru św. Łazarza na liście świadków ${ }^{38}$, oraz krótka wzmianka u Wilhelma $z$ Tyru mówiąca, że córka Amalryka I Sybilla po śmierci ojca w 1174 r. była wychowywana przez Jowitę. Zapewne jej opieka skończyła się wraz z zamążpójściem Sybilli w 1176 r. ${ }^{39}$ Można jednak podejrzewać, że miała ona wpływ na późniejsze postępowanie hrabiny Jafy, a także królowej Jerozolimy.

\section{Melisanda a Baldwin III}

Król Fulko d'Anjou zmarł pod koniec 1143 r. po upadku z konia. Wilhelm $z$ Tyru bardzo obrazowo opisał rozpacz Melisandy po śmierci męża ${ }^{40}$. Biorąc jednak pod uwagę jego wcześniejszą relację o sporze między małżonkami i późniejszą uległość króla, można odnieść wrażenie, że Fulko był tylko dodatkiem do Melisandy, jeśli nawet nie ciężarem. Dlatego niewykluczone, że opisany żal jest tylko figura retoryczna, która wypadało umieścić w tym miejscu. Po śmierci króla znaczenie Melisandy jeszcze wzrosło. Jej starszy syn Baldwin III miał dopiero 13 lat, więc rządziła w jego imieniu aż do 1151 r. Kronikarz stwierdził, że:

Matka króla była kobieta wielkiej mądrości i miała wiele doświadczenia w sprawach świeckich. Wzniosła się tak wysoko ponad normalny status kobiety, że podejmowała naprawdę ważne decyzje. Jej ambicja było dorównanie największym spośród książąt i nieustępowanie im w mądrości. Póki jej syn był nieletni, rządziła królestwem $z$ takimi umiejętnościami i rozwaga, że mogła się równać ze swoimi przodkami. Dopóki jej syn zgadzał się postępować zgodnie $z$ jej radami, sprawy królestwa szły w dobrym kierunku ${ }^{41}$.

\footnotetext{
38 Regesta Regni Hierosolymitani, 140-141.

39 Guillaume de Tyre, Historia Rerum, 1006; William of Tyre, History of Deeds done beyond the seas, vol. 2, 399; Bernard Hamilton, Baldwin IV. Król trędowaty, przeł. K. Jedliński, (Poznań : Wydawnictwo Poznańskie, 2014), 74-76, 227.

40 Guillaume de Tyre, Historia Rerum, 701-702; William of Tyre, History of Deeds done beyond the seas, vol. 2, 134.

41 Erat autem mater, mulier prudentissima, plenam pene in omnibus secularibus negotiis habens experientiam, sexus feminei plane vincens conditionem, ita ut manum mitteret ad fortia; et optimorum principum magnificentiam niteretur aemulari, et corum studia passu non inferiore sectari. Begnum enim, filio adhuc intra puberes annos constituto, tanta rexit industria, tanto procuravit moderamine, ut progenitors suos in ea parte aequare merito
} 
Współcześni Wilhelmowi zwykle niechętnie odnosili się do władzy sprawowanej przez kobietę ${ }^{42}$, ale u niego tej niechęci nie widać. Był on wyraźnie pod wielkim wrażeniem działań królowej. Zresztą nie on jeden. Zachowały się trzy listy Bernarda $z$ Clairvaux do Melisandy, w których prosi on o jej opiekę najpierw nad bratankiem udającym się na wyprawę, a potem nad kilkoma mnichami idacymi $z$ pielgrzymka do Jerozolimy ${ }^{43}$. Pierwszy z nich pochodzi jeszcze z 1142 r., czyli powstał przed śmiercia Fulka. Mimo to Bernard prosił o pomoc nie jego, lecz królowa ${ }^{44}$. Oznaczałoby to, że jej sława i wpływy były doceniane również na Zachodzie. Uznawał je nawet Bernard, który znany był ze swych mizoginistycznych poglądów i nie zawahał się przed krytyką potężnej Eleonory Akwitańskiej ${ }^{45}$.

Po śmierci męża Melisanda została zmuszona do zmierzenia się $z$ nowymi wyzwaniami. Jako regentka decydowała także o wyprawach wojskowych i musiała ostrożnie gospodarować szczupłymi siłami królestwa. W 1144 r. wysłała na pomoc oblężonej Edessie konstabla Jerozolimy Manassesa. Wojska $z$ Jerozolimy nie zdołały jednak zmienić wyniku wojny i miasto upadło ${ }^{46}$. Podczas drugiej krucjaty wraz z synem uczestniczyła w naradzie przed wyprawa na Damaszek. Nie znamy jej szczegółów, ale wiadomo, że podjęte tam decyzje nie wyszły krzyżowcom na dobre ${ }^{47}$. Dwa lata później w 1149 r. wysłała też pomoc zbrojną do Antiochii po śmierci księcia Rajmunda w bitwie. W tym wypadku Wilhelm nie informował o jej udziale, ale armię na własny koszt zebrał patriarcha Jerozolimy wybrany zapewne dzięki wpływom królowej i jej siostry ${ }^{48}$.

Mimo rosnących wpływów Melisanda dbała o zachowanie przyjętych form. Znakomita większość wydawanych przez nią dokumentów

diceretur: ejus quam diu regi voluit consilio filius, optata tranquilitate gavisus est populous, et in prospero cursu regni procedebat negotia (Guillaume de Tyre, Historia Rerum, 707; William of Tyre, History of Deeds done beyond the seas, vol. 2, 139-140).

42 Sandy Bardsley, Women's Roles in the Middle Ages, (London : Greenwood Press, 2007), 193.

43 Patrologia Latina, vol. 182, col. 373, 493-496; Sancti Bernardi Opera, listy nr 206, 288, 289.

${ }^{44}$ Można sądzić, że podobne pismo Bernard wysłał także do Fulka, ale nawet jeśli tak było, to nie dotrwało ono do naszych czasów. Ponadto w liście do swojego bratanka wspomniał o liście do królowej, ale nie do króla, więc zapewne w ogóle do niego nie pisał.

45 Regine Pernoud, Kobieta w czasach wypraw krzyżowych, 75, 77.

46 Jonathan Phillips, The crusades 1095-1197, 37-38.

47 Guillaume de Tyre, Historia Rerum, 711-712, 760; William of Tyre, History of Deeds done beyond the seas, vol. 2, 142, 184-185; Jonathan Phillips, Druga krucjata, 308-311. 48 Guillaume de Tyre, Historia Rerum, 774-775; William of Tyre, History of Deeds done beyond the seas, vol. 2, 199-200. 
ma potwierdzenie najpierw Fulka, a potem Baldwina III. Podobnie jest $z$ dokumentami jej męża i syna. Trudno znaleźć pisma bez formuły zatwierdzenia przez królowa. Jedyny okres, kiedy Melisanda i Baldwin wydawali dokumenty osobno, to rok 1151. Doszło wówczas do otwartego konfliktu między nimi. Według Wilhelma $z$ Tyru zaczął się on od sporu króla $z$ konstablem mianowanym przez matkę - Manassesem. Baldwin uważał, że wpływy i majątek konstabla stały się zbyt duże, a ponadto zapewne już wcześniej myślał o uwolnieniu się spod kurateli (lub opieki) matki. Dlatego koronował się bez jej wiedzy, mimo rady wielu baronów i patriarchy. Następnie wymusił podział królestwa między siebie i Melisandę. Nawet wówczas jednak konflikt nie wygasł, ponieważ król zdobył przydzielony jej Nablus i skierował się w stronę Jerozolimy. Przez jakiś czas oblegał matkę, która zamknęła się w Wieży Dawida, ale nie potrafił zdobyć cytadeli. W końcu dzięki mediacji udało się zawrzeć pokój, a ziemie Melisandy zostały ograniczone do Nablusu i przyległego mu terytorium ${ }^{49}$. W opisie tych wydarzeń zadziwiający wydaje się fakt bierności królowej. To Baldwin zebrał armię, mianował własnego konstabla (Onufrego $z$ Toronu) i zaatakował ziemie matki. Ona, mimo posiadanego wsparcia, nie zdecydowała się odpowiedzieć pięknym za nadobne. Zdawała sobie zapewne sprawę, że doprowadziłoby to do poważnej wojny domowej i w rezultacie osłabienia królestwa. Wilhelm z Tyru, pomimo pewnej sympatii do Baldwina III, w tym sporze wyraźnie opowiada się po stronie Melisandy. Uważał, że do takich kroków namówili króla źli doradcy, a póki słuchał on matki, królestwo Jerozolimy przeżywało okres prosperity.

Mimo powagi konfliktu z 1151 r. można odnieść wrażenie, że późniejsze stosunki matki $z$ synem wróciły do stanu sprzed sporu. Ponownie zatwierdzali wzajemnie swoje nadania i inne dokumenty, w rok później oboje wybrali się do Trypolisu, aby pomóc Hodiernie w sporze $z$ mężem, około 1157 r. prowadzili dwie uzupełniajace się kampanie - Baldwin pod Szajzarem, a Melisanda w Zajordanii ${ }^{50}$, a potem król nie protestował, kiedy jego matka i ciotka wpływały na wybór nowego patriarchy Jerozolimy. Najwyraźniej Melisanda zdała sobie sprawę, że nie może do końca

49 Guillaume de Tyre, Historia Rerum, 779-783; William of Tyre, History of Deeds done beyond the seas, vol. 2, 204-207.

50 Guillaume de Tyre, Historia Rerum, 852-853; William of Tyre, History of Deeds done beyond the seas, vol. 2, 269. 
życia odcinać syna od rządów, a Baldwin, że rada i wpływy matki sa nieodzowne przy skutecznym sprawowaniu owych rządów. Zwłaszcza że mimo ograniczenia ziem będących w jej bezpośrednim posiadaniu wielu wasali królestwa pozostawało jej wiernych, a Konstancja z Antiochii zawdzięczała jej regencję w swoim księstwie. Dlatego Baldwin, choć przejął władzę w państwie, wcią̇ musiał się liczyć ze znacznymi wpływami matki $i$ to zapewne aż do jej śmierci.

W miarę dokładną datę śmierci znamy tylko w przypadku Melisandy. Wilhelm $z$ Tyru poinformował, że w 1160 r. królowa poważnie zachorowała. Odwiedziły ją wówczas dwie młodsze siostry - Hodierna i Jowita. Zapewne już nie udało się jej wyzdrowieć, ponieważ kronikarz pisał o długiej chorobie i śmierci królowej we wrześniu $1161 \mathrm{r} .{ }^{51}$ Dzięki tym informacjom wiemy, że w chwili śmierci Melisandy jej dwie najmłodsze siostry jeszcze żyły. Alicja zmarła na pewno po 1145 r., a przed 1151 r., czyli około dziesięć lat przed starszą siostrą. Hodierna zmarła na pewno po Melisandzie, ale przed 1164 r., kiedy to Rajmund III trafił do niewoli. Regentem został Amalryk I, więc można podejrzewać, że matka hrabiego już nie żyła. Najmłodsza $z$ sióstr - Jowita na pewno żyła jeszcze w 1175 r., ponieważ zachował się dokument Baldwina IV odnoszacy się do opatki klasztoru św. Łazarza. Ponadto nikt nie informuje, żeby zmarła podczas opieki nad Sybilla, więc zmarła na pewno po 1176 r. W każdym razie można stwierdzić, że znaczenie córek Baldwina II zostało znacznie ograniczone po śmierci najstarszej z nich, ponieważ tylko ona miała dość umiejętności i wpływów, by zabezpieczać pozycje pozostałych.

\section{Zakończenie}

Pierwotny plan artykułu zakładał równy udział wszystkich czterech córek Baldwina II. Okazało się jednak, że postać Melisandy skutecznie przyćmiewa jej siostry i innych jej współczesnych. Częściowo ze względu na zajmowana pozycję, a częściowo ze względu na silny charakter, królowa Jerozolimy przyjęła na siebie rolę opiekunki młodszych sióstr. Można dostrzec tę tendencję nawet jeszcze przed śmiercia Baldwina II. To zapewne jej wpływ na ojca pozwolił Alicji zachować posiadłości w księstwie Antiochii. Troska Melisandy o rodzeństwo jest

51 Guillaume de Tyre, Historia Rerum, 867, 877; William of Tyre, History of Deeds done beyond the seas, vol. 2, 283, 291. 
jednak najlepiej widoczna po $1131 \mathrm{r}$. Wówczas stanowiła już wyraźny bufor pomiędzy Fulkiem a niepokorna Alicją z Antiochii, broniła Hodierny przed naciskami męża i zapewniła bezpieczną przyszłość Jowicie. Starała się także dbać o swoja siostrzenicę Konstancję, zwłaszcza po śmierci jej męża w bitwie $z$ Nur-ad-Dinem. Wydaje się, że forma opieki lub nawet kontroli, która działała skutecznie w wypadku innych kobiet $z$ jej rodziny, okazała się nieskuteczna odnośnie do jej własnego syna. Zgodnie $z$ ówczesnymi zwyczajami zdecydowana większość kobiet była w jakimś stopniu uzależniona od mężczyzn. Być może dlatego młodsze siostry Melisandy stosunkowo łatwo się jej podporządkowały. Królowa po śmierci ojca przyjęła na siebie typowo męską rolę w średniowiecznej rodzinie. Stąd podporządkowanie sióstr, sprzeciw dorastającego Baldwina III i uwagi Wilhelma $z$ Tyru porównujące Melisandę z najpotężniejszymi książętami królestwa Jerozolimy. Wydaje się też, że pozostałe siostry nie spotykały się bez niej. Nie zachował się żaden dokument $z$ obecnością w jakiejkolwiek formie (wystawcy, podpisu czy na liście świadków) choćby trzech $z$ nich. Nie mamy także informacji o takich spotkaniach $\mathrm{u}$ Wilhelma $z$ Tyru. Dysponujemy tylko informacjami o spotkaniach Melisandy $z$ innymi siostrami pojedynczo. Jedynym momentem, kiedy królowa na pewno widziała jednocześnie Hodiernę i Jowitę, był okres jej smiertelnej choroby w 1160 r., kiedy to przybyły w odwiedziny. $Z$ tego wniosek, że Melisanda nie tylko opiekowała się młodszym rodzeństwem, lecz także inicjowała kontakty.

$Z$ powodu tak bardzo dominującej pozycji Melisandy może być trudno scharakteryzować pozostałe siostry. Najbardziej wyrazista postacią wydaje się Alicja $z$ Antiochii. Wilhelm $z$ Tyru wyraźnie uważał, że dażyła tylko do władzy i brakowało jej odpowiedzialności za państwo. Jako przykłady podawał trzy próby odebrania miasta córce i kontakty dyplomatyczne $z$ Imadem-ad-Din Zenghim. Wówczas jednak takie kontakty utrzymywało bardzo wielu możnych, a te księżnej Antiochii nie sa potwierdzone. Ponadto, patrząc na sytuację $z$ innej strony, można dojść do wniosku, że problemem była kolejność zgonów w rodzinie. Mąż Alicji - Boemund II zginał w bitwie przed śmiercia Baldwina II. Przy ostatniej próbie przejęcia Antiochii królem Jerozolimy był Fulko, który pod wpływem Melisandy powstrzymał się od interwencji. Podobna sytuacja miała miejsce po zamachu na Rajmunda II $z$ Trypolisu w 1152 r. Baldwin III nie oponował przeciw przekazaniu regencji Hodiernie, mimo że była $\mathrm{w}$ takiej samej sytuacji, jak wcześniej starsza siostra. Oznaczałoby to, 
że Alicja, mimo braku praw do tronu, miała szansę na regencję, gdyby władzę w Jerozolimie sprawował zależny od żony Fulko. Dążenie do władzy dotyczyło niemal wszystkich możnych. Trudno więc stwierdzić, jaką władczynią okazałaby się Alicja. Można na pewno powiedzieć, że nie brakowało jej uporu ani odwagi, skoro trzykrotnie starała się zasiąść na tronie antiocheńskim.

Niestety osobowość Hodierny, taka jak ukazuja ją źródła, jest niepełna. $Z$ jednej strony hrabina Trypolisu wydaje się najbardziej wycofana $z$ czterech sióstr. Może to jednak wynikać ze specyficznych relacji z mężem, zwłaszcza po drugiej krucjacie. $Z$ drugiej jednak strony w $1152 \mathrm{r}$. nie cofnęła się przed konfliktem $z$ Rajmundem. Niewykluczone też, że wezwała na pomoc Melisandę. Największym problemem jest brak źródeł dotyczacych jej trzyletniej regencji w hrabstwie Trypolisu za niepełnoletniego Rajmunda III. Dopiero po poznaniu tego okresu można byłoby wnioskować o jej umiejętnościach rządzenia i charakterze.

Najmłodsza siostra - Jowita pojawia się w źródłach najrzadziej. Ponadto, podobnie jak Hodierna, w dużym stopniu korzystała z pomocy Melisandy. Warto jednak zauważyć, że Jowita była jedyna z czterech sióstr, która w dorosłym życiu nigdy nie była zależna od jakiegokolwiek mężczyzny. Fakt, że została mniszką, nakładał na nią wiele ograniczeń, ale pozycja matki przełożonej w połączeniu z pokrewieństwem $z$ królowa dawała jej też specyficzna, lecz niezagrożona pozycję i wyjątkowe możliwości, które na pewno nieraz wykorzystała. W źródłach potwierdzone są dwa takie przypadki: raz, kiedy wraz z Melisandą wpływały na wybór patriarchy i drugi raz, kiedy przez kilka lat wychowywała przyszłą królową - Sybillę jerozolimską. Bardzo możliwe, że spotkanie opatek klasztorów $z$ królestwa $z$ Melisandą w 1157 r. dotyczyło nie tylko wymiany dóbr $z$ joannitami, lecz także wyboru patriarchy. Oznaczałoby to, że królowa razem $z$ najmłodsza siostra zyskały sobie przychylność wielu żeńskich klasztorów, co dawało im znaczne, ale trudno uchwytne zakulisowe wpływy. W takim wypadku Jowita urastałaby do najbliższej współpracownicy królowej, przynajmniej w sprawach kościelnych, a może i wewnętrznych. Niewykluczone zatem, że charakterologicznie przypominała najstarsza siostrę, ale mniej znaczaca pozycja Jowity i zdolności Melisandy sprawiły, że nie mogła osiagnać porównywalnego znaczenia w państwie.

Wszystkie cztery siostry, każda na swój sposób, wyrastały ponad przeciętność i nie mieściły się $\mathrm{w}$ rolach pełnionych przez kobiety w średniowieczu, nawet jeśli bierzemy pod uwage te pochodzace $z$ rodzin kró- 
lewskich i ksiażęcych. Najbardziej wyróżniała się oczywiście Melisanda, która poza rolą córki, żony, matki i królowej pełniła także funkcję pełnoprawnego władcy oraz dowódcy wojskowego na poziomie strategicznym. W niektórych wypadkach jej nowe role ostro kolidowały $z$ tradycyjnymi, ale $z$ czasem udawało jej się je pogodzić. Inaczej było w wypadku Alicji. Wydaje się, że dą̇̇yła do roli władcy na tyle mocno, że zbyt poważnie zaniedbała role córki i matki. Ewentualnie można też powiedzieć, że postrzeganie jej przez pryzmat tradycyjnych ról przez otoczenie nie pozwoliło na ich zmianę. Jedyna, która ze swoich ról niemal nie wychodziła, była Hodierna. Tak się przynajmniej wydaje po lekturze źródeł. Wilhelm z Tyru o jej sporze $z$ mężem pisze dopiero pod 1152 r. Zarówno wcześniej, jak i później pozostawała dla niego prawie niewidoczna. Nie pisał o niej nawet $w$ okresie jej regencji, a $z$ oficjalnych dokumentów nie da się wyciagać wniosków na temat jej relacji z Rajmundem II lub Rajmundem III. Możliwe jednak, że konflikt małżeński wspomniany bardzo późno trwał już od dawna, a Hodierna nie była w nim bierna. Podobnie może być w wypadku jej trzyletnich rządów w Trypolisie. Jowicie przypadła w udziale zupełnie inna rola niż jej siostrom, ale chyba dość dobrze się w niej odnajdowała, skoro kronika nie informowała o głosach sprzeciwu podczas jej wyboru na matkę przełożoną w bardzo młodym wieku. Wyraźnie potrafiła też godzić rolę zakonnicy $z$ nieokreśloną rolą pełnioną w polityczno-kościelnym otoczeniu Melisandy, skoro nie wahała się interweniować podczas elekcji patriarchy, a sprzeciw wyraziło tylko dwóch biskupów.

\section{Bibliografia}

\section{Źródła:}

d'Albon, Marquis (ed.). Cartulaire general de l'Ordre du Temple, (Paris : Honore Champion, 1913).

Delaborde, Francois (ed.). Chartes de Terre Sainte, (Paris : Albert Fontemoing, 1880).

Hagenmayer, Heinrich (ed.). Fulcheri Carnotensis Historia Hierosolymitana, (Heidelberg : Carl Winters, 1913).

Huygens, Robert (ed.). Willelmi Tyrensis Archiepiscopi Chronicon, Corpus Christianorum Continuatio Medievalis, (Turnholt : Brepols, 1986), vol. 38, 38a. 
LeClercq, Jean, Rochais, Henri (ed.). Sancti Bernardi Opera, (Rome : 1979), listy $\mathrm{nr}$ 206, 289, 354, 355.

Le Roulx, Jean Delaville (ed.). Cartulaire general de l'Odre des Hospitalliers de Saint Jean de Jerusalem, (Paris : Ernest Leroux, 1844), vol. 1.

Marescandoli, Salvatore (ed.). Codice diplomatico del Sacro Militare Ordine Gerosolimitano oggi di Malta, (Lucca, 1733).

Migne, Jean-Paul (ed.). Patrologiae Cursus Completus, Patrologia Latina, (Paris, 1859), vol. 182.

Röhricht, Reinhold (ed.). Regesta Regni Hierosolymitani, (Innsbruck : Academica Wagneriana, 1893).

Roziere, Euegene de (ed.). Cartulaire de l'Eglise du Saint Sepulcre de Jerusalem, (Paris : Imprimerie National, 1849).

Tyre, Guillaume de. Historia Rerum in partibus transmarinis gestarum. Recueil des Historiens des Croisades. Historiens Occidentaux, (Paris : Imprimerie Royale, 1844), vol. 1.

Tyre, William of. History of Deeds done beyond the seas, (ed.) Emily Babcock, August Krey, (New York : Columbia University Press, 1943).

\section{Opracowania:}

Asbridge, Thoms. Krucjaty. Wojna o Ziemię Święta, przeł. Natalia Rataj, Mateusz Józefowicz, (Kraków : Wydawnictwo Astra, 2015). ISBN 978-8389981-59-2.

Barber, Malcolm. The crusader states, (New Haven : Yale University Press, 2012). ISBN 978-0300113129.

Bardsley, Sandy. Women's Roles in the Middle Ages, (London : Greenwood Press, 2007). ISBN 978-0313336355.

Edbury, Peter, Rowe, John Gordon. William of Tyre. Historian of the Latin East, (New York : Cambridge University Press, 1990). ISBN 9780521267663.

Friedman, Yvonne. Encounter between enemies. Captivity and ransom, (Boston-Leiden : Brill, 2002). ISBN 978-9004117068.

Hamilton, Bernard. Baldwin IV. Król trędowaty, przeł. Jakub Jedliński, (Poznań : Wydawnictwo Poznańskie, 2014). ISBN 978-83-7177-983-1.

Handyside, Phillip. The Old French William of Tyre, (Boston-Leiden : Brill, 2015). ISBN 978-90-04-25688-0. 
Hodgson, Natasha. Women, crusading and holy land in the historical narrative, (Woodbridge : Boydell Press, 2003). ISBN 9781783272709.

Jotischky, Andrew. Crusading and the Crusader states, (New York : Taylor\&Francis Ltd, 2013). ISBN 978-0582418516.

La Monte, John. Monarchia feudalna $w$ łacińskim królestwie jerozolimskim w latach 1100-1291, przeł. Konrad Ziółkowski, (Oświęcim : Napoleon V, 2015). ISBN 978-83-7889-452-0.

Pernoud, Regine. Kobieta w czasach wypraw krzyżowych, przeł. Iwona Badowska, (Gdańsk : Marabut, 2002). ISBN 83-916703-3-3.

Phillips, Jonathan. Druga krucjata. Rozszerzanie granic chrześcijaństwa, przeł. Norbert Radomski, (Poznań : Rebis, 2013). ISBN 978-83-7510805-7.

Phillips, Jonathan. The crusades 1095-1197, (London : Pearson Longman, 2002). ISBN 978-0582328228.

Prawer, Joshua. Królestwo jerozolimskie. Europejski kolonializm w średniowieczu, przeł. Grzegorz Smółka, (Oświęcim : Napoleon V, 2017). ISBN 978-83-65746-48-1.

Runciman, Steven. Dzieje wypraw krzyżowych, przeł. Jerzy Schwakopf, (Warszawa : Państwowy Instytut Wydawniczy, 1987), t. 1-2. ISBN 830601457X. 